\title{
Trafficking of endoplasmic reticulum-retained recombinant proteins is unpredictable in Arabidopsis thaliana
}

\author{
Thomas De Meyer ${ }^{1,2}$ and Ann Depicker ${ }^{1,2 *}$ \\ ${ }^{1}$ Department of Plant Systems Biology, VIB, Plant-made Antibodies and Immunogens, Gent, Belgium \\ ${ }^{2}$ Department of Plant Biotechnology and Bioinformatics, Ghent University, Gent, Belgium
}

\section{Edited by:}

Els J. M. Van Damme, Ghent

University, Belgium

Reviewed by:

Richard Strasser, University of Natural Resources and Life

Sciences, Austria

Jurgen Denecke, The University of

Leeds, UK

Els J. M. Van Damme, Ghent

University, Belgium

${ }^{*}$ Correspondence:

Ann Depicker, Department

Plant Systems Biology, VIB,

Technologiepark 927,

Gent 9052, Belgium

e-mail:anpic@psb.vib-ugent.be
A wide variety of recombinant proteins has been produced in the dicot model plant Arabidopsis thaliana. Many of these proteins are targeted for secretion by means of an $\mathrm{N}$-terminal endoplasmic reticulum (ER) signal peptide. In addition, they can also be designed for ER retention by adding a C-terminal H/KDEL-tag. Despite extensive knowledge of the protein trafficking pathways, the final protein destination, especially of such $\mathrm{H} / \mathrm{KDEL}$-tagged recombinant proteins, is unpredictable. In this respect, glycoproteins are ideal study objects. Microscopy experiments reveal their deposition pattern and characterization of their $\mathrm{N}$-glycans aids in elucidating the trafficking. Here, we combine microscopy and $\mathrm{N}$-glycosylation data generated in Arabidopsis leaves and seeds, and highlight the lack of a decent understanding of heterologous protein trafficking.

Keywords: molecular farming, antibody production, dense vesicle, ER-derived vesicle, protein storage vacuole, KDEL, seed-specific expression

\section{INTRODUCTION}

Recombinant proteins are often produced in eukaryotic host organisms to ensure proper folding, disulfide bridge formation and $\mathrm{N}$-glycan processing. By fusing the protein of interest to an N-terminal endoplasmic reticulum (ER) signal peptide, they co-translationally enter the ER and travel along the secretory pathway, where $\mathrm{N}$-glycosylation takes place on the consensus Asn-X-Ser/Thr motif. The N-glycan composition is of crucial importance for the protein structure, stability, half-life and function, and is primarily determined by the production host (Jacobs and Callewaert, 2009). In molecular farming, where plants are used as production systems, heterologous proteins targeted for secretion typically contain complex-type $\mathrm{N}$-glycans with $\beta-1,2$-xylose and core $\alpha-1,3$-fucose residues. These are potentially immunogenic and are hence unwanted for therapeutic protein production (Gomord et al., 2005). Therefore, significant efforts went into the development of glyco-engineered production platforms that prevent plant-specific N-glycosylation in the Golgi complex (Gomord et al., 2010; Castilho and Steinkellner, 2012). Alternatively, heterologous glycoproteins can be retained in the ER by adding a C-terminal H/KDEL-tag. Whereas both HDEL- and KDEL-tagged endogenous proteins are found in plants (Napier et al., 1992), the vast majority of heterologously expressed, ER-retained proteins carry the KDEL-tag. Typical for $\mathrm{H} / \mathrm{KDEL}$-tagging is the formation of $\mathrm{Man}_{8} \mathrm{GlcNAc}_{2}$ (Man8) Nglycans. However, as ER retention is based on retrograde trafficking from cis-Golgi to ER, the glycoproteins transiently encounter cis-Golgi processing enzymes, such as $\alpha-1,2$-mannosidase, resulting in partially trimmed $\mathrm{N}$-glycans, such as Man7 and Man6. In addition to the desired N-glycan profile, H/KDEL-tagging can also enhance protein accumulation levels, presumably because the ER is a favorable compartment for protein folding and storage (Fiedler et al., 1997; Petruccelli et al., 2006). However, such an increased accumulation is not always observed (Loos et al., 2011a,b).

In contrast to this black and white distinction between secretion and H/KDEL-mediated ER retention, numerous protein localization studies reported unexpected outcomes. Drawing clear conclusions from these experiments proved hard, because of the different proteins of interest, plant species, tissues, promoters, regulatory sequences, targeting signals and achieved accumulation levels (De Muynck et al., 2010). Moreover, protein trafficking has also been shown to change throughout development (Arcalis et al., 2010; Wang et al., 2012). In this review, we provide a detailed overview of protein localization studies in leaves and seeds of the dicot model plant, Arabidopsis thaliana. By limiting ourselves to Arabidopsis, we eliminate organismal specificity and highlight tissue (i.e., leaves vs. seeds) and protein specificity in heterologous protein trafficking.

In Arabidopsis, most recombinant proteins have been produced in seeds, providing the advantage of long-term storage capacity, high protein content and productivity, and no interference with vegetative plant growth (Stoger et al., 2005; Kermode, 2012). In head-to-head comparisons with the same protein of interest, Arabidopsis seeds were more positively evaluated than those of tobacco, petunia and maize in terms of protein accumulation levels (Loos et al., 2011a; Morandini et al., 2011). However, the impact of such comparisons is limited due to the different efficiencies of regulatory sequences and codon usage across organisms. Nevertheless, one of the highest accumulation levels achieved in plants is still that of the seed-produced G4 scFv in Arabidopsis (i.e., 36.5\% of total soluble protein (TSP) in 
homozygous seeds) (De Jaeger et al., 2002). De Wilde et al. (2013) showed that $\mathrm{VHH}-\mathrm{Fc}$ and $\mathrm{scFv}-\mathrm{Fc}$ accumulation levels of $1 \%$ or more in Arabidopsis seeds trigger an unfolded protein response, because an enhanced expression of genes involved in protein folding, glycosylation, protein translocation, degradation and vesicle trafficking was observed. However, despite such an altered gene expression profile, Arabidopsis seeds often fail to provide a $100 \%$ N-glycan site occupancy (Table 1B; 3-18 and 26).

\section{TRAFFICKING OF PROTEINS TARGETED FOR SECRETION}

In leaves, heterologous proteins that carry an N-terminal ER signal peptide, are efficiently secreted to the apoplast (De Wilde et al., 1996; Peeters et al., 2001) (Table 1A; 1-3) and mainly carry complex-type N-glycans (Schahs et al., 2007) (Table 1A; 5 and 6). Of note, Loos et al. (2011b) found that an anti-hepatitis A virus scFv-Fc (HA78) contained complex-type N-glycans as expected, while an anti-HIV scFv-Fc (2G12) was completely covered with oligomannosidic N-glycans (Table 1A; 7 and 8). Because the authors could not detect antigen-binding activity for this $2 \mathrm{G} 12 \mathrm{scFv}-\mathrm{Fc}$, they postulated that it was not folded properly and activated the ER-associated protein degradation pathway, hence preventing further N-glycan maturation in the Golgi apparatus.

In seeds, despite successful examples of protein secretion with complex-type $\mathrm{N}$-glycans, some exceptions stress the lack of a decent understanding of secreted heterologous protein trafficking. For example, HA78 and 2G12 monoclonal antibodies (mAbs) were both found in the apoplast and in electron-opaque Golgiattached dense vesicles (DVs) in developing seeds (Loos et al., 2011a) (Table 1B; 8 and 11). DVs are distinct from clathrincoated vesicles that normally mediate protein secretion, and are considered the main pathway for massive seed storage protein transport from the trans-Golgi network to the protein storage vacuole (PSV) (Robinson et al., 2005; Vitale and Hinz, 2005; Otegui et al., 2006; Wang et al., 2012) (Figure 1; blue stars). Their electron-opaque content reflects the aggregated state of the storage proteins. Possibly, the highly abundant storage proteins, such as globulins, exhibit a dominant sorting effect that leads to partial trapping of the heterologous proteins in DVs. A similar mechanism, imposed by endogenous seed storage proteins, has been proposed for recombinant phytase in ER-derived prolamin bodies of rice endosperm (Drakakaki et al., 2006). In agreement with the co-sorting hypothesis to the PSV via DVs in Arabidopsis, glucocerebrosidase that was targeted for secretion, was mainly located in the apoplast and to a minor extent in PSVs in mature seeds ( $\mathrm{He}$ et al., 2012a) (Table 1B; 22). Alternatively, partial mislocalization of secreted proteins to DVs and PSVs can also be explained by the presence of cryptic vacuolar specific sequences (Jolliffe et al., 2005).

Both the HA78 and 2 G12 mAbs were produced as scFv-Fc moieties, using the same targeting and regulatory sequences (Loos et al., 2011b) (Table 1B; 13 and 16). On the one hand, labeling in apoplast and Golgi-attached DVs was obtained for HA78 scFv-Fc (identical as for HA78 mAb) in developing Arabidopsis seeds. In mature seeds, PSVs were devoid of label, so the question remains where the DV-localized HA78 scFv-Fcs of the developing embryos ended up. Instead, the final destinations of HA78 scFv-Fc were the apoplast and "globular, membrane-delimited structures of around 200 to $400 \mathrm{~nm}$ in diameter." The latter were termed ERderived vesicles (ERVs), because ribosomes were observed on their surface, but their specific formation in later developmental stages was unclear. This dual deposition pattern was in accordance with the presence of both complex-type and oligomannosidic $\mathrm{N}$ glycans. On the other hand, $2 \mathrm{G} 12 \mathrm{scFv}-\mathrm{Fc}$ exclusively contained Man7 and Man8 N-glycans, and was observed in ERVs and the swollen nuclear envelope. This aberrant localization is in agreement with the proposed improper folding of $2 \mathrm{G} 12 \mathrm{scFv}-\mathrm{Fc}$ (see above in Arabidopsis leaves).

\section{TRAFFICKING OF PROTEINS TARGETED FOR ER-RETENTION}

Only one study has been performed in Arabidopsis leaves, in which a KDEL-tagged Fab fragment was detected intracellularly, most likely in the endomembrane system (Peeters et al., 2001) (Table 1A; 4).

In seeds, only Loos et al. (2011a) conclusively demonstrated successful ER retention, more in particular for a minor fraction of KDEL-tagged 2G12 mAb (Table 1B; 10). All other studies describe distinct deposition patterns (Figure 1). First, the most prevalent observation is the formation of ERVs, in a process that is not fully understood (Van Droogenbroeck et al., 2007; Loos et al., 2011b; Morandini et al., 2011; He et al., 2012b) (Table 1B; $3,14,17,20$ and 24). Their origin resembles KDEL-vesicles (KV) of Vigna mungo seeds, by which SH-EP, a KDEL-tagged vacuolar proteinase, is shuttled from the ER to the PSV upon germination (Toyooka et al., 2000). Moreover, the C-terminal KDEL-tag of SH-EP was shown to be essential for KV formation (Okamoto et al., 2003). Similarly, after producing GFP-KDEL in tobacco leaves, so-called protein bodies were observed in most transformants with a GFP accumulation level of at least $0.2 \%$ of TSP (Conley et al., 2009; Gutiérrez et al., 2013). Taken together, it seems that the KDEL-tag ensures a local protein build-up in the ER lumen, from which ERVs, KVs or protein bodies are formed. From results obtained in mature Arabidopsis seeds, two hypotheses were made. On the one hand, ERVs can represent the endstage of heterologous protein trafficking (Van Droogenbroeck et al., 2007; Morandini et al., 2011; Loos et al., 2011b), which sometimes are observed together with equal amounts of protein deposited in the swollen nuclear envelope (Loos et al., 2011b) (Table 1B, 14 and 17). On the other hand, ERVs can mediate a Golgi-independent pathway to the PSV. This was demonstrated by the EndoH sensitivity of the GAD67/65 glycoprotein (Morandini et al., 2011) (Table 1B; 19) and the large fraction of oligomannosidic N-glycans on 2G12 mAb (Loos et al., 2011a) (Table 1B; 10). A similar ER-derived Golgi-independent pathway toward the PSV has been described for endogenous seed storage proteins in pumpkin seeds, where the shuttle vesicles were termed precursor-accumulating (PAC) vesicles (Hara-Nishimura et al., 1998). The authors hypothesized that the PAC pathway has evolved for efficient, massive transport of unglycosylated seed storage proteins to the PSV. Of note, vacuole biogenesis might also represent an ER-to-vacuole route, because the ER was recently proposed as the main membrane source for lytic vacuole formation (Viotti et al., 2013). Although such a mechanism has not yet been observed for PSVs, it is tempting to state that some ERretained heterologous proteins are trapped into a PSV precursor in a similar process (Figure 1). 
Table 1 | Overview of recombinant protein production in Arabidopsis leaves (A) and seeds (B), in which white boxes indicate recombinant proteins targeted for secretion, and gray boxes correspond to KDEL-tagged proteins.

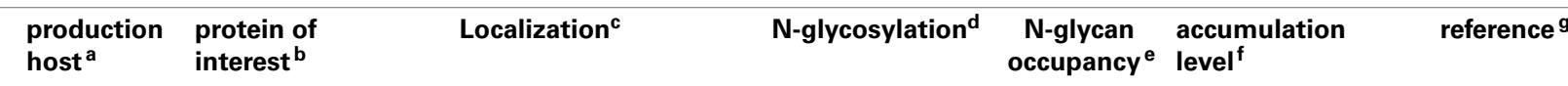

\section{(A) PROTEIN ANALYSIS IN ARABIDOPSIS LEAVES}

\begin{tabular}{|c|c|c|c|c|c|c|c|}
\hline 1 & WT & MAK33 mAb & apoplast & n.d. & n.d. & n.d. & $\begin{array}{l}\text { De Wilde et al., } \\
1996\end{array}$ \\
\hline 2 & WT & MAK33 Fab & apoplast & n.a. & n.a. & n.d. & $\begin{array}{l}\text { De Wilde et al., } \\
1996\end{array}$ \\
\hline 3 & WT & MAK33 Fab & apoplast & n.a. & n.a. & up to $6.5 \%$ of TSP & Peeters et al., 2001 \\
\hline 4 & WT & MAK33 Fab & endomembrane system & n.a. & n.a. & up to $5.9 \%$ of TSP & Peeters et al., 2001 \\
\hline 6 & XT/FT k.o. & $2 \mathrm{G} 12 \mathrm{mAb}$ & n.d. & $\begin{array}{l}\text { GnGn, MGn, } \\
\text { Man4-9 }\end{array}$ & $100 \%$ & $\begin{array}{l}0.05-0.2 \% \text { of TSP in } \\
\text { young plants }\end{array}$ & Schahs et al., 2007 \\
\hline 7 & WT & $2 \mathrm{G} 12 \mathrm{scFv}-\mathrm{Fc}$ & n.d. & Man4-9 & n.d. & n.d. & Loos et al., 2011b \\
\hline 8 & WT & HA78 scFv-Fc & n.d. & $\begin{array}{l}\text { GnGnXF, MGnXF, } \\
\text { MMXF }\end{array}$ & n.d. & n.d. & Loos et al., 2011b \\
\hline 2 & $c g l$ & $\begin{array}{l}\text { human } \\
\alpha \text {-L-iduronidase }\end{array}$ & $\begin{array}{l}\text { apoplast (developing } \\
\text { seeds) }\end{array}$ & $\begin{array}{l}\text { mainly } \\
\text { oligomannosidic }\end{array}$ & n.d. & up to $1.8 \%$ of TSP & $\begin{array}{l}\text { Downing et al., } \\
2006\end{array}$ \\
\hline
\end{tabular}

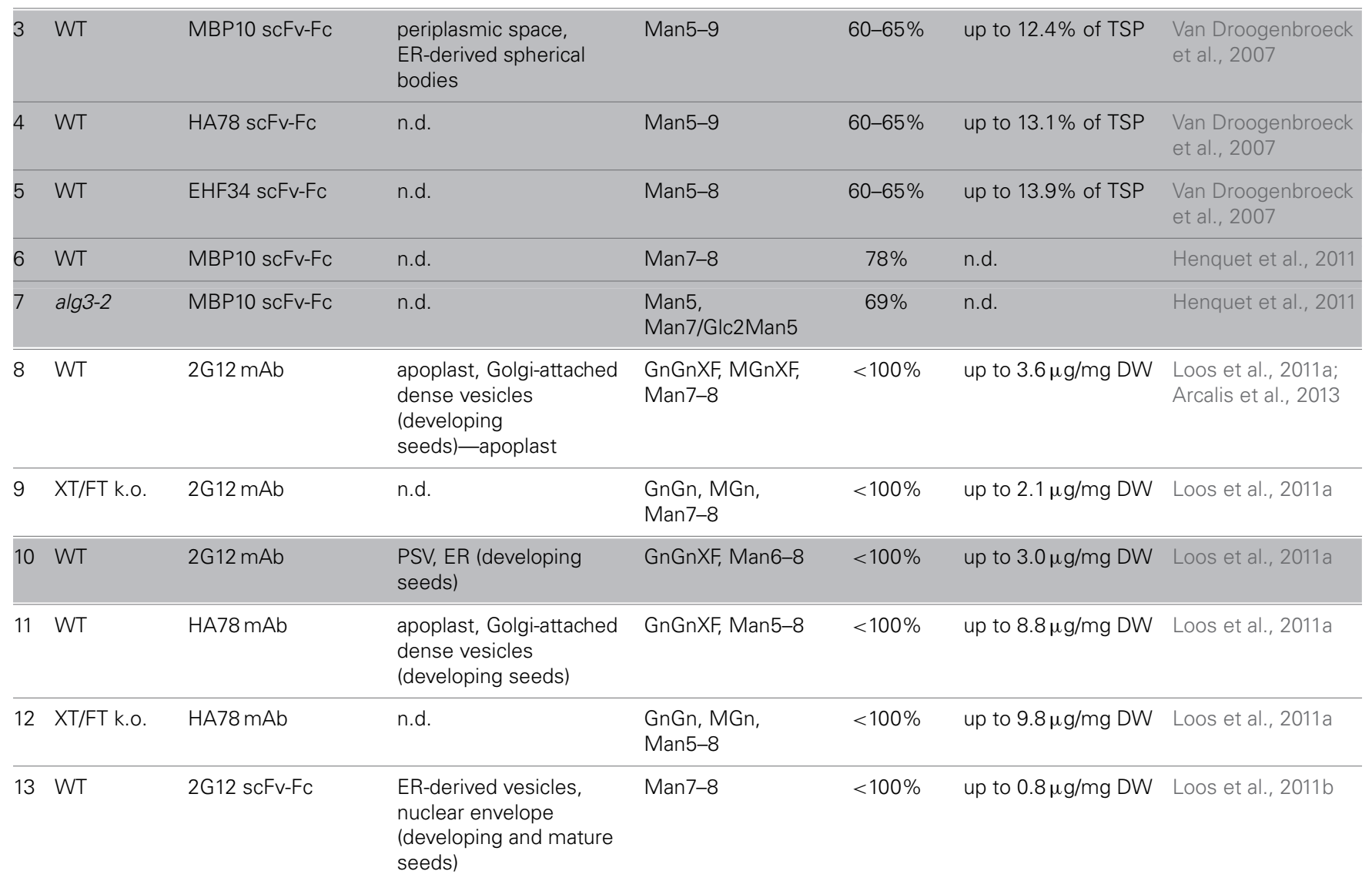




\section{Table 1 | Continued}

\begin{tabular}{|c|c|c|c|c|c|c|c|}
\hline & $\begin{array}{l}\text { production } \\
\text { host }^{\text {a }}\end{array}$ & $\begin{array}{l}\text { protein of } \\
\text { interest }^{b}\end{array}$ & Localization $^{c}$ & N-glycosylation ${ }^{d}$ & $\begin{array}{c}\text { N-glycan } \\
\text { occupancy }\end{array}$ & $\begin{array}{l}\text { accumulation } \\
\text { level }^{f}\end{array}$ & reference $^{g}$ \\
\hline 14 & WT & $2 \mathrm{G} 12 \mathrm{scFv}-\mathrm{Fc}$ & $\begin{array}{l}\text { ER-derived vesicles, } \\
\text { nuclear envelope }\end{array}$ & Man7-8 & $<100 \%$ & up to $0.8 \mu \mathrm{g} / \mathrm{mg} \mathrm{DW}$ & Loos et al., 2011b \\
\hline 15 & XT/FT k.o. & $2 \mathrm{G} 12 \mathrm{scFv}-\mathrm{Fc}$ & n.d. & Man7-8 & $<100 \%$ & up to $3.5 \mu \mathrm{g} / \mathrm{mg} \mathrm{DW}$ & Loos et al., 2011b \\
\hline 16 & WT & HA78 scFv-Fc & $\begin{array}{l}\text { apoplast, Golgi, } \\
\text { Golgi-attached dense } \\
\text { vesicles (developing } \\
\text { seeds)_apoplast, } \\
\text { ER-derived vesicles }\end{array}$ & $\begin{array}{l}\text { GnGnXF, MGnXF, } \\
\text { Man5-9 }\end{array}$ & $70 \%$ & up to $8.0 \mu \mathrm{g} / \mathrm{mg} \mathrm{DW}$ & Loos et al., 2011b \\
\hline 17 & WT & HA78 scFv-Fc & $\begin{array}{l}\text { PSV, ER-derived vesicles } \\
\text { (developing } \\
\text { seeds)-ER-derived } \\
\text { vesicles, nuclear } \\
\text { envelope }\end{array}$ & Man7-8 & $<100 \%$ & up to $3.9 \mu \mathrm{g} / \mathrm{mg}$ DW & Loos et al., 2011b \\
\hline 19 & WT & $\begin{array}{l}\text { glutamic acid } \\
\text { decarboxylase } \\
\text { GAD67/65 }\end{array}$ & PSV & $\begin{array}{l}\text { oligomannosidic } \\
\text { N-glycans }\end{array}$ & $100 \%$ & $\begin{array}{l}1.5-5.4 \% \text { of TSP (up } \\
\text { to } 4.5 \mu \mathrm{g} / \mathrm{mg} \mathrm{DW} \text { ) }\end{array}$ & $\begin{array}{l}\text { Morandini et al., } \\
2011\end{array}$ \\
\hline 20 & WT & interleukin-10 & $\begin{array}{l}\text { apoplast, ER-like } \\
\text { membrane } \\
\text { compartments }\end{array}$ & n.a. & n.a. & $\begin{array}{l}0.1-0.7 \% \text { of TSP (up } \\
\text { to } 0.82 \mu \mathrm{g} / \mathrm{mg} \text { DW) }\end{array}$ & $\begin{array}{l}\text { Morandini et al., } \\
2011\end{array}$ \\
\hline 21 & WT & proinsulin & PSV & n.a. & n.a. & $\begin{array}{l}<0.01 \% \text { of TSP } \\
\text { (up to } 0.005 \mu \mathrm{g} / \mathrm{mg} \\
\text { DW) }\end{array}$ & $\begin{array}{l}\text { Morandini et al., } \\
2011\end{array}$ \\
\hline 22 & $c g l$ & glucocerebrosidase & apoplast, PSV & $\begin{array}{l}\text { MGnXF, MMXF, } \\
\text { Man5F, Man4-8 }\end{array}$ & n.d. & up to $0.1 \%$ of TSP & He et al., 2012a \\
\hline 25 & WT & $\begin{array}{l}\text { pVHH7-hGFc } \\
\text { (VHH-Fc) }\end{array}$ & n.d. & $\begin{array}{l}\text { N-glycans without } \\
\alpha-1,3 \text {-fucosylation }\end{array}$ & $100 \%$ & up to $16.3 \%$ of TSP & De Buck et al., 2013 \\
\hline 26 & WT & sV3A (sVHH-Fc) & n.d. & $\begin{array}{l}\text { oligomannosidic } \\
\text { N-glycans }\end{array}$ & $<100 \%$ & up to $5 \mu \mathrm{g} / \mathrm{mg} \mathrm{DW}$ & Virdi et al., 2013 \\
\hline 27 & WT & $\begin{array}{l}\text { GP3, GP4 and GP5 } \\
\text { antigens }\end{array}$ & n.d. & $\begin{array}{l}\text { oligomannosidic } \\
\text { N-glycans }\end{array}$ & n.d. & up to $2.7 \%$ of TSP & Piron et al., 2014 \\
\hline
\end{tabular}

n.d., not determined; n.a., not applicable.

a alg3-2, a-1,3-mannosyltransferase mutant (Henquet et al., 2008); cgl, complex glycan mutant (Von Schaewen et al., 1993); WT, wild-type; XT/FT k.o., B-1,2xylosyltransferase and core $\alpha-1,3$-fucosyltransferase knockout line (Strasser et al., 2004).

${ }^{b} F a b$, fragment antigen-binding; $m A b$, monoclonal antibody; $s c F v-F c$, single-chain variable fragment fused to a fragment crystallisable; VHH-Fc, variable domain of the heavy chain of the heavy-chain antibody fused to a fragment crystallisable.

${ }^{c}$ In mature, dry seeds unless mentioned otherwise.

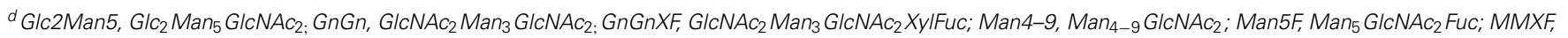

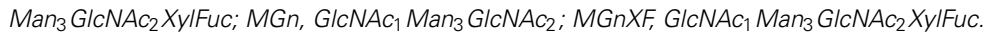

e Sometimes determined ourselves based on available figures in the corresponding references.

${ }^{f}$ In our experience, $1 \%$ of TSP corresponds to about $2.5 \mu \mathrm{g} / \mathrm{mg}$ DW. DW, dry weight; TSP, total soluble protein.

${ }^{g}$ Studies were ordered chronologically. 


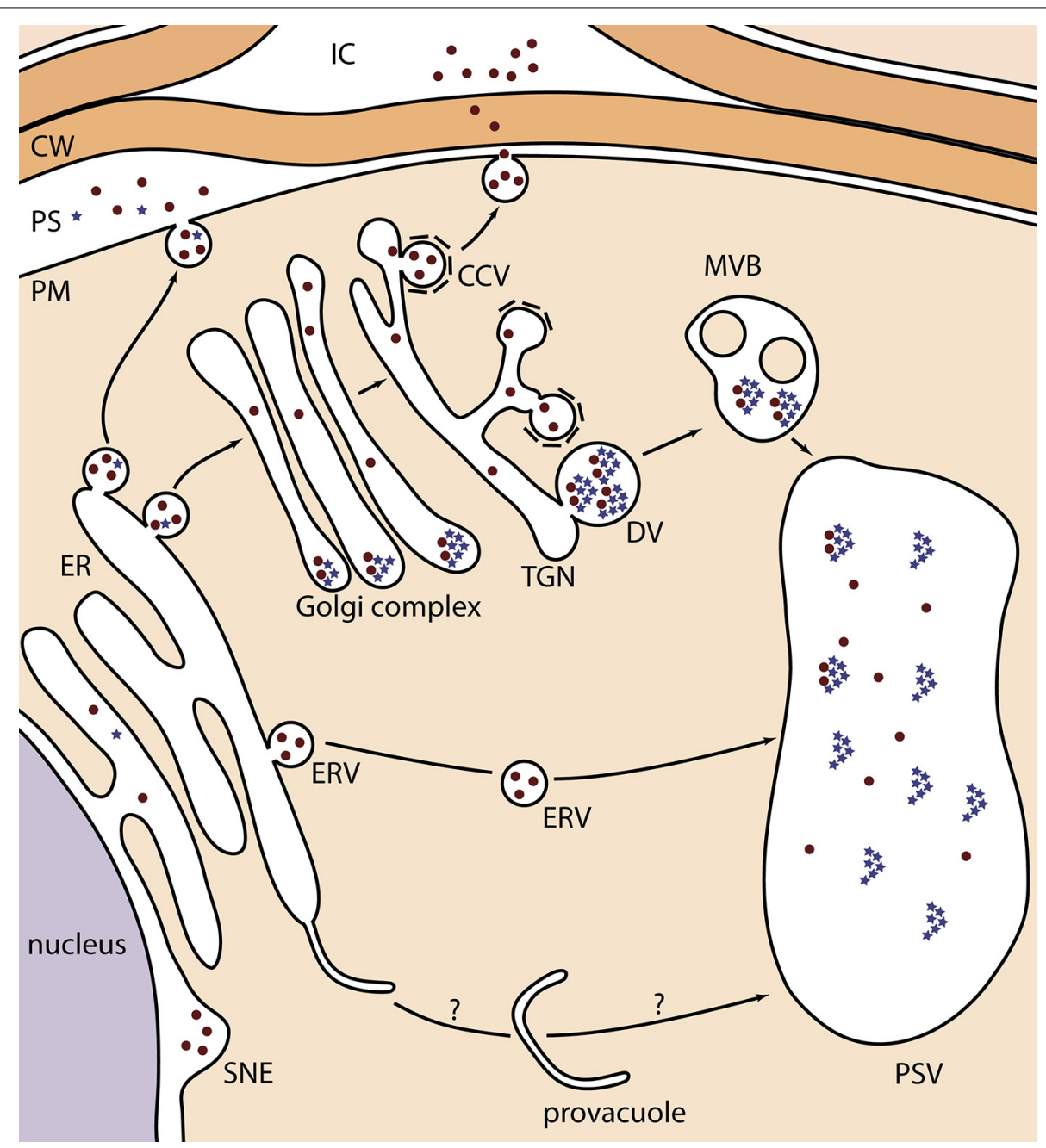

FIGURE 1 | Schematic representation of the different localizations of KDEL-tagged recombinant proteins in Arabidopsis seeds. Recombinant proteins are depicted as brown dots, and globulin seed storage proteins as blue stars. During their transport, globulins aggregate in the periphery of the Golgi cisternae, from where they bud into DVs toward the PSV. In one occasion, they were observed in the PS because of a disturbed protein trafficking of endogenous proteins (Van Droogenbroeck et al., 2007). The
ER-to-provacuole hypothesis, as depicted at the bottom, is based on recent observations of lytic vacuole biogenesis (Viotti et al., 2013). CCV, clathrin-coated vesicle; CW, cell wall; DV, dense vesicle; ER, endoplasmic reticulum; ERV, ER-derived vesicle; IC, intercellular space; MVB, multivesicular body; PS, periplasmic space; PSV, protein storage vacuole; PM, plasma membrane; SNE, swollen nuclear envelope; TGN, trans-Golgi network.
Second, partial leakage to the Golgi has been observed because KDEL-tagged proteins accumulated in the apoplast (Morandini et al., 2011) (Table 1B; 20) or carried complex-type N-glycans (Loos et al., 2011a) (Table 1B; 10). Such ER leakage has also been described in Medicago and tobacco (Triguero et al., 2005; Petruccelli et al., 2006; Abranches et al., 2008). The authors suggested several factors that might influence successful ER retention. For example, one should consider the amount of KDELtags per assembled molecule, and the accessibility and integrity of the KDEL-tag. Remarkably, based on western blot analysis of subcellular fractions, He et al. (2012b) suggested a Golgidependent route toward the PSV for KDEL-tagged human $\alpha$-Liduronidase (Table 1B; 24). Unfortunately, electron microscopy localization studies on mature seeds confirming this hypothesis, were lacking.
Third, after producing KDEL-tagged MBP10 scFv-Fc in Arabidopsis seeds, an electron-opaque periplasmic space (PS) between the plasma membrane and cell wall was observed in which most of the MBP10 was deposited (Van Droogenbroeck et al., 2007) (Table 1B; 3). Moreover, MBP10 exclusively contained oligomannosidic N-glycans, pointing to a Golgiindependent route from the ER to the PS. Because ER-resident proteins, such as calreticulin and binding protein, were also present in the PS, and because of the very high MBP10 accumulation level (up to $12.4 \%$ of TSP), the authors proposed an overcharge of the ER storage capacity. Interestingly, globulin storage proteins were also deposited in the PS.

In several other studies, localization experiments were outof-scope. However, $\mathrm{N}$-glycan analyses were performed and only oligomannosidic N-glycans were detected (Henquet et al., 2011; 
De Buck et al., 2013; Virdi et al., 2013; Piron et al., 2014) (Table 1B; 6, 7 and 25-27). Although the authors probably assumed successful ER retention, we conclude that, based on the aforementioned detailed localization studies, these KDEL-tagged glycoproteins can also reside in ERVs, the PSV (by bypassing the Golgi complex) or the PS.

\section{CONCLUDING REMARKS}

It is critical for recombinant protein production that the platform is reliable and predictable in terms of product quality. In this respect, the ER retention of KDEL-tagged recombinant proteins in Arabidopsis, has proven to be unpredictable, and similar observations were made in other plant production systems. Therefore, $\mathrm{H} / \mathrm{KDEL}$-tagged proteins, produced in plants, should always be analyzed in terms of final destination and N-glycan composition, unless of course, if the actual N-glycan composition is of less importance (e.g., for diagnostic proteins) and does not influence the final product performance.

Obviously, additional investigations are needed. For example, one could analyse the influence of the protein accumulation level by comparing protein localizations in low and high expressing lines. Alternatively, the promoter sequences used might also severely impact the observed protein localization. To this end, promoters with different temporal and spatial expression patterns, especially during seed development, could be worthwhile to study. Further, deletion and swapping experiments can reveal whether particular protein domains of the heterologous protein contain certain localization motifs resulting in the lack of ER retention. Finally, most of the manuscripts discussed here, did not verify KDEL-tag accessibility or integrity. For future reports on $\mathrm{H} / \mathrm{KDEL}$-tagged protein production in plants, it would thus be valuable to include, for example, western blot or immunoprecipitation analyses with commercially available anti-H/KDEL antibodies. In case recognition by these antibodies fails, linker sequences can be used to improve H/KDEL-tag accessibility. We conclude that such investigations will result in a much better predictability of the ER retention of overexpressed H/KDELtagged proteins in plants, and eventually contribute to the further establishment of the field of plant molecular farming.

\section{ACKNOWLEDGMENTS}

The authors thank Annick Bleys, Daniel Van Damme and Steffen Vanneste for help in preparing the manuscript.

\section{REFERENCES}

Abranches, R., Arcalis, E., Marcel, S., Altmann, F., Ribeiro-Pedro, M., Rodriguez, J., et al. (2008). Functional specialization of Medicago truncatula leaves and seeds does not affect the subcellular localization of a recombinant protein. Planta 227, 649-658. doi: 10.1007/s00425-007-0647-3

Arcalis, E., Stadlmann, J., Marcel, S., Drakakaki, G., Winter, V., Rodriguez, J., et al. (2010). The changing fate of a secretory glycoprotein in developing maize endosperm. Plant Physiol. 153, 693-702. doi: 10.1104/pp.109. 152363

Arcalis, E., Stadlmann, J., Rademacher, T., Marcel, S., Sack, M., Altmann, F., et al. (2013). Plant species and organ influence the structure and subcellular localization of recombinant glycoproteins. Plant Mol. Biol. 83, 105-117. doi: 10.1007/s11103-013-0049-9

Castilho, A., and Steinkellner, H. (2012). Glyco-engineering in plants to produce human-like N-glycan structures. Biotechnol. J. 7, 1088-1098. doi: 10.1002/biot. 201200032
Conley, A. J., Joensuu, J. J., Menassa, R., and Brandle, J. E. (2009). Induction of protein body formation in plant leaves by elastin-like polypeptide fusions. BMC Biol. 7:48. doi: 10.1186/1741-7007-7-48

De Buck, S., Nolf, J., De Meyer, T., Virdi, V., De Wilde, K., Van Lerberge, E., et al. (2013). Fusion of an Fc chain to a VHH boosts the accumulation levels in Arabidopsis seeds. Plant Biotechnol. J. 11, 1006-1016. doi: 10.1111/pbi. 12094

De Jaeger, G., Scheffer, S., Jacobs, A., Zambre, M., Zobell, O., Goossens, A., et al. (2002). Boosting heterologous protein production in transgenic dicotyledonous seeds using Phaseolus vulgaris regulatory sequences. Nat. Biotechnol. 20, 1265-1268. doi: 10.1038/nbt755

De Muynck, B., Navarre, C., and Boutry, M. (2010). Production of antibodies in plants: status after twenty years. Plant Biotechnol. J. 8, 529-563. doi: 10.1111/j.1467-7652.2009.00494.x

De Wilde, C., De Neve, M., De Rycke, R., Bruyns, A. M., De Jaeger, G., Van Montagu, M., et al. (1996). Intact antigen-binding MAK33 antibody and Fab fragment accumulate in intercellular spaces of Arabidopsis thaliana. Plant Sci. 114, 233-241. doi: 10.1016/0168-9452(96)04331-2

De Wilde, K., De Buck, S., Vanneste, K., and Depicker, A. (2013). Recombinant antibody production in Arabidopsis seeds triggers an unfolded protein response. Plant Physiol. 161, 1021-1033. doi: 10.1104/pp.112.209718

Downing, W. L., Galpin, J. D., Clemens, S., Lauzon, S. M., Samuels, A L., Pidkowich, M. S., et al. (2006). Synthesis of enzymatically active human alpha-L-iduronidase in Arabidopsis cgl (complex glycan-deficient) seeds. Plant Biotechnol. J. 4, 169-181. doi: 10.1111/j.1467-7652.2005. 00166.x

Drakakaki, G., Marcel, S., Arcalis, E., Altmann, F., Gonzalez-Melendi, P., Fischer, R., et al. (2006). The intracellular fate of a recombinant protein is tissue dependent. Plant Physiol. 141, 578-586. doi: 10.1104/pp.106.076661

Fiedler, U., Phillips, J., Artsaenko, O., and Conrad, U. (1997). Optimization of scFv antibody production in transgenic plants. Immunotechnology 3, 205-216. doi: 10.1016/S1380-2933(97)00014-6

Gomord, V., Chamberlain, P., Jefferis, R., and Faye, L. (2005). Biopharmaceutical production in plants: problems, solutions and opportunities. Trends Biotechnol. 23, 559-565. doi: 10.1016/j.tibtech.2005.09.003

Gomord, V., Fitchette, A. C., Menu-Bouaouiche, L., Saint-Jore-Dupas, C., Plasson, C., Michaud, D., et al. (2010). Plant-specific glycosylation patterns in the context of therapeutic protein production. Plant Biotechnol. J. 8, 564-587. doi: 10.1111/j.1467-7652.2009.00497.x

Gutiérrez, S. P., Saberianfar, R., Kohalmi, S. E., and Menassa, R. (2013). Protein body formation in stable transgenic tobacco expressing elastin-like polypeptide and hydrophobin fusion proteins. BMC Biotechnol. 13:40. doi: 10.1186/14726750-13-40

Hara-Nishimura, I., Shimada, T., Hatano, K., Takeuchi, Y., and Nishimura, M. (1998). Transport of storage proteins to protein storage vacuoles is mediated by large precursor-accumulating vesicles. Plant Cell 10, 825-836. doi: 10.1105/tpc. 10.5 .825

He, X., Galpin, J. D., Tropak, M. B., Mahuran, D., Haselhorst, T., Von Itzstein, M., et al. (2012a). Production of active human glucocerebrosidase in seeds of Arabidopsis thaliana complex-glycan-deficient (cgl) plants. Glycobiology 22, 492-503. doi: 10.1093/glycob/cwr157

He, X., Haselhorst, T., Von Itzstein, M., Kolarich, D., Packer, N. H., and Kermode, A. R. (2012b). Influence of an ER-retention signal on the N-glycosylation of recombinant human $\alpha$-L-iduronidase generated in seeds of Arabidopsis. Plant Mol. Biol. 79, 157-169. doi: 10.1007/s11103-012-9902-5

Henquet, M., Eigenhuijsen, J., Hesselink, T., Spiegel, H., Schreuder, M., Van Duijn, E., et al. (2011). Characterization of the single-chain Fv-Fc antibody MBP10 produced in Arabidopsis alg3 mutant seeds. Transgenic Res. 20, 1033-1042. doi: 10.1007/s11248-010-9475-5

Henquet, M., Lehle, L., Schreuder, M., Rouwendal, G., Molthoff, J., Helsper, J., et al. (2008). Identification of the gene encoding the alpha1,3-mannosyltransferase (ALG3) in Arabidopsis and characterization of downstream N-glycan processing. Plant Cell 20, 1652-1664. doi: 10.1105/tpc.108.060731

Jacobs, P. P., and Callewaert, N. (2009). N-glycosylation engineering of biopharmaceutical expression systems. Curr. Mol. Med. 9, 774-800. doi: 10.2174/156652409789105552

Jolliffe, N. A., Craddock, C. P., and Frigerio, L. (2005). Pathways for protein transport to seed storage vacuoles. Biochem. Soc. Trans. 33, 1016-1018. doi: 10.1042/BST20051016 
Kermode, A. R. (2012). "Seed expression systems for molecular farming," in Molecular Farming in Plants: Recent Advances and Future Prospects, eds A. Wang and S. Ma (Dordrecht; Heidelberg; London; New York, NY: Springer), 89-123.

Loos, A., Van Droogenbroeck, B., Hillmer, S., Grass, J., Kunert, R., Cao, J., et al. (2011a). Production of monoclonal antibodies with a controlled $N$ glycosylation pattern in seeds of Arabidopsis thaliana. Plant Biotechnol. J. 9, 179-192. doi: 10.1111/j.1467-7652.2010.00540.x

Loos, A., Van Droogenbroeck, B., Hillmer, S., Grass, J., Pabst, M., Castilho, A., et al. (2011b). Expression of antibody fragments with a controlled $N$ glycosylation pattern and induction of endoplasmic reticulum-derived vesicles in seeds of Arabidopsis. Plant Physiol. 155, 2036-2048. doi: 10.1104/pp.110. 171330

Morandini, F., Avesani, L., Bortesi, L., Van Droogenbroeck, B., De Wilde, K., Arcalis, E., et al. (2011). Non-food/feed seeds as biofactories for the high-yield production of recombinant pharmaceuticals. Plant Biotechnol. J. 9, 911-921. doi: 10.1111/j.1467-7652.2011.00605.x

Napier, R. M., Fowke, L. C., Hawes, C., Lewis, M., and Pelham, H. R. B. (1992). Immunological evidence that plants use both HDEL and KDEL for targeting proteins to the endoplasmic reticulum. J. Cell Sci. 102, 261-271.

Okamoto, T., Shimada, T., Hara-Nishimura, I., Nishimura, M., and Minamikawa, T. (2003). C-terminal KDEL sequence of a KDEL-tailed cysteine proteinase (sulfhydryl-endopeptidase) is involved in formation of KDEL vesicle and in efficient vacuolar transport of sulfhydryl-endopeptidase. Plant Physiol. 132, 1892-1900. doi: 10.1104/pp.103.021147

Otegui, M. S., Herder, R., Schulze, J., Jung, R., and Staehelin, L. A. (2006). The proteolytic processing of seed storage proteins in Arabidopsis embryo cells starts in the multivesicular bodies. Plant Cell 18, 2567-2581. doi: 10.1105/tpc.106.040931

Peeters, K., De Wilde, C., and Depicker, A. (2001). Highly efficient targeting and accumulation of a Fab fragment within the secretory pathway and apoplast of Arabidopsis thaliana. Eur. J. Biochem. 268, 4251-4260. doi: 10.1046/j.14321327.2001.02340.x

Petruccelli, S., Otegui, M. S., Lareu, F., Tran Dinh, O., Fitchette, A.-C., Circosta, A., et al. (2006). A KDEL-tagged monoclonal antibody is efficiently retained in the endoplasmic reticulum in leaves, but is both partially secreted and sorted to protein storage vacuoles in seeds. Plant Biotechnol. J. 4, 511-527. doi: 10.1111/j.1467-7652.2006.00200.x

Piron, R., De Koker, S., De Paepe, A., Goossens, J., Grooten, J., Nauwynck, H., et al. (2014). Boosting in planta production of antigens derived from the Porcine Reproductive and Respiratory Syndrome Virus (PRRSV) and subsequent evaluation of their immunogenicity. PLOS ONE 9:e91386. doi: 10.1371/journal.pone.0091386

Robinson, D. G., Oliviusson, P., and Hinz, G. (2005). Protein sorting to the storage vacuoles of plants: a critical appraisal. Traffic 6, 615-625. doi: 10.1111/j.16000854.2005.00303.x

Schahs, M., Strasser, R., Stadlmann, J., Kunert, R., Rademacher, T., and Steinkellner, H. (2007). Production of a monoclonal antibody in plants with a humanized N-glycosylation pattern. Plant Biotechnol. J. 5, 657-663. doi: 10.1111/j.14677652.2007.00273.x

Stoger, E., Ma, J. K.-C., Fischer, R., and Christou, P. (2005). Sowing the seeds of success: pharmaceutical proteins from plants. Curr. Opin. Biotechnol. 16, 167-173. doi: 10.1016/j.copbio.2005.01.005
Strasser, R., Altmann, F., Mach, L., Glossl, J., and Steinkellner, H. (2004). Generation of Arabidopsis thaliana plants with complex N-glycans lacking beta 1,2-linked xylose and core alpha 1,3-linked fucose. FEBS Lett. 561, 132-136. doi: 10.1016/S0014-5793(04)00150-4

Toyooka, K., Okamoto, T., and Minamikawa, T. (2000). Mass transport of proform of a KDEL-tailed cysteine proteinase (SH-EP) to protein storage vacuoles by endoplasmic reticulum-derived vesicle is involved in protein mobilization in germinating seeds. J. Cell Biol. 148, 453-464. doi: 10.1083/jcb.148.3.453

Triguero, A., Cabrera, G., Cremata, J. A., Yuen, C.-T., Wheeler, J., and Ramírez, N. I. (2005). Plant-derived mouse IgG monoclonal antibody fused to KDEL endoplasmic reticulum-retention signal is N-glycosylated homogeneously throughout the plant with mostly high-mannose-type N-glycans. Plant Biotechnol. J. 3, 449-457. doi: 10.1111/j.1467-7652.2005.00137.x

Van Droogenbroeck, B., Cao, J., Stadlmann, J., Altmann, F., Colanesi, S., Hillmer, S., et al. (2007). Aberrant localization and underglycosylation of highly accumulating single-chain Fv-Fc antibodies in transgenic Arabidopsis seeds. Proc. Natl. Acad. Sci. U.S.A. 104, 1430-1435. doi: 10.1073/pnas.0609997104

Viotti, C., Kruger, F., Krebs, M., Neubert, C., Fink, F., Lupanga, U., et al. (2013). The endoplasmic reticulum is the main membrane source for biogenesis of the lytic vacuole in Arabidopsis. Plant Cell 25, 3434-3449. doi: 10.1105/tpc.113.114827

Virdi, V., Coddens, A., De Buck, S., Millet, S., Goddeeris, B. M., Cox, E., et al. (2013). Orally fed seeds producing designer IgAs protect weaned piglets against enterotoxigenic Escherichia coli infection. Proc. Natl. Acad. Sci. U.S.A. 110, 11809-11814. doi: 10.1073/pnas.1301975110

Vitale, A., and Hinz, G. (2005). Sorting of proteins to storage vacuoles: how many mechanisms? Trends Plant Sci. 10, 316-323. doi: 10.1016/j.tplants.2005.05.001

Von Schaewen, A., Sturm, A., Oneill, J., and Chrispeels, M. J. (1993). Isolation of a mutant Arabidopsis plant that lacks N-acetyl glucosaminyl transferase-I and is unable to synthesize Golgi-modified complex N-linked glycans. Plant Physiol. 102, 1109-1118. doi: 10.1104/pp.102.4.1109

Wang, J. Q., Tse, Y. C., Hinz, G., Robinson, D. G., and Jiang, L. W. (2012). Storage globulins pass through the Golgi apparatus and multivesicular bodies in the absence of dense vesicle formation during early stages of cotyledon development in mung bean. J. Exp. Bot. 63, 1367-1380. doi: 10.1093/jxb/err366

Conflict of Interest Statement: The authors declare that the research was conducted in the absence of any commercial or financial relationships that could be construed as a potential conflict of interest.

Received: 23 June 2014; accepted: 28 August 2014; published online: 15 September 2014.

Citation: De Meyer T and Depicker A (2014) Trafficking of endoplasmic reticulumretained recombinant proteins is unpredictable in Arabidopsis thaliana. Front. Plant Sci. 5:473. doi: 10.3389/fpls.2014.00473

This article was submitted to Plant Physiology, a section of the journal Frontiers in Plant Science.

Copyright () 2014 De Meyer and Depicker. This is an open-access article distributed under the terms of the Creative Commons Attribution License (CC BY). The use, distribution or reproduction in other forums is permitted, provided the original author(s) or licensor are credited and that the original publication in this journal is cited, in accordance with accepted academic practice. No use, distribution or reproduction is permitted which does not comply with these terms. 